\title{
University of New Mexico
}

UNM Digital Repository

University Libraries \& Learning Sciences Faculty

Publications

Scholarly Communication - Departments

2001

\section{Library budgets and academic library rankings in times of transition.}

Johann van Reenen

Follow this and additional works at: http://digitalrepository.unm.edu/ulls_fsp

\section{Recommended Citation}

van Reenen, Johann. "Library budgets and academic library rankings in times of transition.." The Bottom Line: Managing Library Finances 14, 4 (2001): 213-218. http://digitalrepository.unm.edu/ulls_fsp/18

This Article is brought to you for free and open access by the Scholarly Communication - Departments at UNM Digital Repository. It has been accepted for inclusion in University Libraries \& Learning Sciences Faculty Publications by an authorized administrator of UNM Digital Repository. For more information, please contactdisc@unm.edu. 


\title{
Library budgets and academic library rankings in times of transition.
}

\author{
Johann van Reenen*, University of New Mexico, Albuquergue, NM \\ NOTE: This is an early version of an article that is peer reviewed and published as: \\ Library budgets and academic library ratings in times of transition. The Bottom Line: \\ Managing Library Finances, 2001, 14(4): 213-218
}

\begin{abstract}
An analysis of the ability of a particular library to significantly increase its Association of Research Libraries (ARL) ranking in a reasonable time period is presented. A discussion follows to show why this is not a useful objective at a time when academic libraries are transitioning to new types of products and services made possible by emerging technologies. There are various initiatives underway in the United States and Europe to create more meaningful performance measures for academic libraries.
\end{abstract}

\section{Keywords: Evaluation, Performance measures, Metrics, Academic Library rankings Introduction}

The Association of Research Libraries (ARL) has recognized the need to transition to more meaningful outcome and impact measures from the current collection of simple input data. To improve the value of their current statistics, Kyrillidou (1995) used ratio analysis. She used three kinds of ratios: percentages, relational ratios, and annual change factors. These are not indicators of quality and cannot be used to set benchmarks. Yet, these are used regularly by libraries to see how they rank against their peers on a range of indicators, and even to set targets for where they aim to rank in future. The reliability of this type data can be easily effected by inconsistency of data collection, over time and between types of academic libraries, and in constantly changing 
contexts. Thus, the ARL New Measures Initiative was formed at the 1999 Membership Meeting when the ARL Statistics and Measurement Committee and the ARL Research Library Leadership and Management Committee decided to respond to requests from members for new ways to measure new (mostly electronic) products and emerging services. The New measures homepage at $<$ http://www.arl.org/stats/newmeas/newmeas.html $>$ is extremely informative and provides regular updates on progress.

Library administrators and university faculty frequently use the current rankings to prove that their library is under funded compared to their peer group, while university funding authorities may use the ratings to prove that funding is sufficient. The clustering of libraries into peer groups, alone, is problematic. Dole's (1994) collection analysis study highlighted this, coming to the useful conclusion that it is more meaningful to match collecting patterns to university priorities and to allocate resources that reflect the strengths, missions, and goals of the university. In the 1999/2000 financial year the author was asked by the then Associate-Provost for Research and Dean of Graduate Studies at our university, Dr Nasir Ahmed, about the true value of rankings. This article is derived from our discussions. I would like to acknowledge the valuable analysis, ideas and extensive input of Dr. Ahmed.

\section{Methodology}

The purpose of this analysis is twofold:

- to confirm that the main objective of ARL ranking is to measure the relative size of university libraries

- to demonstrate that it is unrealistic to expect a particular library (in this case our test library, the University of New Mexico Libraries) to be ranked much higher than about 5 points up, due to budgetary and other resource realities. 
The 1996-97 ARL statistics was chosen as this represents a "normal" year before additional questions were added to the ARL survey. Although the data is older, the principles that need to be illustrated will work with any year's data.

Table 1 provides a listing of ARL rankings for 1996-97 for the top 60 universities. Note that the Test Library's ranking is 49, while Harvard University's ranking is 1; see column 2 of Table 1. The term Reference University in Table 1 (row 1) has nothing to do with the ARL ranking. It refers to a hypothetical university that will be used to carry out the analysis.

The data entries used to arrive at the above ranking are shown in columns 3 through 7 of Table1, and these data entries respectively represent:

- Vols in Library $\quad$----> Number of volumes held

- Vols added ----> Number of volumes added during the previous fiscal year

- Current serials $\quad$----> Number of current serials

- Permanent staff $\quad$----> Number of permanent staff

- Total expend $\quad$----> Total operating expenditures

Take in Table 1.

\section{Analysis}

The Reference University is a hypothetical university with resources that exceed those of any university that is ranked by the ARL in Table 1 . Next, columns 8 through 12 are calculated as follows:

Column 8 (Ratio 1):

Column 9 (Ratio 2):

Column 10 (Ratio 3):
\# of volumes held at an institution \# of volumes held at the Reference Univ.

\# of volumes added at an institution during previous FY

\# of volumes added at the Reference Univ. during previous FY

\# of current serials at an institution

\# of current serials at the Reference Univ. 
Column 11 (Ratio 4):

Column 12 (Ratio 5):

\author{
\# of permanent staff at an institution \\ \# of permanent staff at the Reference Univ.
}

Total operating expenditures at an institution

Total operating expenditures at the Reference Univ.

The sum of Ratios 1 through Ratio 5 yields the figures listed in Column 13 (Index). Note that the maximum value attained by "Index" is 5 and is attained by the Reference University. The ranking use here is based on the numerical value of this Index and depicted in Column 14 (Ranking based on Index). Institutions ranked in this manner are further identified in 4 groups in Column 15 (Group \#).

\section{Observations:}

1. Although the ARL rankings are not identical with the Index-ranking, they are very similar and some disagreements occur only within a group. Note that the ARL ranking of 49 for the Test Library (UNM) compares closely with the Index ranking, which is 48 . This confirms that the ARL ranking simply reflects the relative size of university libraries.

2. Suppose the Test Library's ranking is to improve to 45 based on Index ranking. Then from Table 1 it follows that Test Library's index value must increase from 1.055 to 1.1044 , which yields 0.049 . There are numerous ways of trying to accomplish this, as illustrated by a couple of examples.

One way is to simply increase each of the values of Ratio1 through Ratio 5 by the amount 0.0098 , which is 0.049 divided by 5 since there are five Ratio values. This results in the following increases that must occur for the desired ranking improvement:

- Vols in Library $\quad$----> $\quad$ must increase by $0.0098 \times$ (Vols. in Library at Reference Univ) $=.0098 \times 15,000,000=147,000$

- Vols added ----> $\quad$ must increase by $0.0098 \times$ (Vols. added at Reference Univ.) $=.0098 \times 300,000=2,940$

- Current serials ----> must increase by 0.0098 x (Current serials at Reference Univ.) $=0.0098 \times 110,000=1,078$

- Permanent staff $\quad$----> $\quad$ must increase by 0.0098 x (Permanent staff at Reference Univ.) 


$$
=0.0098 \times 1,100=10.78 \mathrm{FTE}
$$

- Total expend ----> must increase by $0.0098 \times$ (Total expenditures at Reference Univ. $)=0.0098 \times \$ 75,000,000=\$ 750,000$

Based on 1996-97, these are the kind of increases Test University (UNM) would need, which are unrealistic considering its, and for that matter, any library's resource situation.

Alternately, suppose we just try increasing the total expenditures. This would require an increase of $0.045 \times$ (Total expenditures at Reference University) $=0.045 \times \$ 75,000,000=\$ 3,375,000$. This represents a $20 \%$ increase relative to Test Library's total expenditures for FY96-97. Clearly, this is again unrealistic.

This demonstrates that it is unrealistic to expect the Test Library to be ranked any higher than about 45 , due to budgetary and other resource realities and proves the initial two problem statements true.

The ARL statistics are, however, extremely useful to track industry-wide trends such as the continuing pressure on library budgets due to inflation. ARL Statistics continue to show decreased purchasing power for academic libraries. Borrowing between libraries increased by $116 \%$ from the benchmark year (1986) as libraries were able to buy fewer and fewer needed materials. Also, the addition of data on instructional presentations, reference transactions and circulation statistics make it possible for libraries to do internal ratio analyses that compare activities to physical collections, and so forth.

\section{Improving quality and effectiveness measures for academic libraries.}

The work of the ARL New Measures Initiative broadens our understanding of library characteristics and performance. Comprehensive reviews of the state of inquiry into library performance measures are provided annually through the ARL Bimonthly Report, available online at http://www.arl.org/newsltr/index.html. Thus far their deliberations have identified eight areas for 
which measures would be helpful: Ease and Breadth of Access, User Satisfaction, Library Impact on Teaching and Learning, Library Impact on Research, Cost Effectiveness of Library Operations and Services, Library Facilities and Space, Market Penetration, and Organizational Capacity Ability. Another important movement towards new measures is the Northumbria International Conferences on Performance Measurement organized by the School of Information Studies, University of Northumbria at Newcastle, UK. Summary reports of these conferences $(1995,1997$, and 1999, 2001) and more information on the measures are available online at http://thenortheast.com/pm3web/index.htm and http://www.arl.org/stats/north/index.html.

\section{Discussion}

Many campus constituents are concerned about continuing to measure library "success" by using the current ARL ranking system. They fear that efforts to continuously rank the campus library as high as possible in ARL using quantitative data, may seriously distort the allocation of resources over time, and even the quality of collections and services to users. Many key indicators of success for the emerging digital library are not currently measured by ARL statistics and may in fact count against a library which is focusing it's resources on developing new types of services and products.

It is clear that determinants of library quality must be linked to the university's educational and research outcomes. Thus, we need to be able to measure the library's:

- $\quad$ services in meeting customer expectations

- collections for pertinence (print and electronic)

- $\quad$ success in providing lifelong knowledge acquisition skills

- $\quad$ information literacy outcomes

- $\quad$ cost-effectiveness in processing electronic and print materials

- user satisfaction ratings, using a nationally approved survey instrument such as the LibQual+ instrument currently in phase 3 testing by about 40 academic libraries in the United States. 
- $\quad$ success in attracting external funding

- number and quality of consortial agreements

- number and quality of networked workstations

- $\quad$ and so forth.

During this time of "ratings transition", library managers will have to educate campus constituencies, from administrators to users, about the value of possibly not rating well, but doing the work needed to secure a successful information future for the university.

A simple example that many research libraries have faced during the last decade is that of outsourcing non-core functions. For instance, if books arrived pre-processed and ready to be shelved, fewer staff is needed, resulting in lower ratings. As soon as outsourcing begins to pay off the initial investment and savings occur, this too may result in lower ratings!

\section{Conclusion}

Two major realities facing academic libraries will drive evaluation in future:

- the concept of collection self-sufficiency is a fallacy. More and more information will be obtained through temporary or permanent electronic access to information stored elsewhere. (Keith 1997)

- the library will have to prove its value in contributing to key institutional outcomes. An outcome of particular importance to accreditation bodies is the teaching-learning role of libraries. The latter is well established in the literature (Lindauer 1998) but difficult to measure.

This analysis provides a clear argument that can be used to explain why diverting money from one paradigm to another will have radical effects on traditional ratings but does not mean that the library is regressing. It fits with Pritchard's (1996) conclusions as early as 1996 but still true today that: 
"Academic libraries will continue for some time to be obligated to provide traditional acquisitions and public services, yet they are already shifting their approaches in response to the explosion of networked information resources, third-party providers, self-publishing, and many other variations of the traditional mechanisms for producing, organizing, and delivering scholarly information.... The future vitality of libraries in academia will be dependent on whether they can dynamically and continually prove their value to the overall educational endeavor. This value must be documented at a level that transcends specific formats of information, locations of collections and locations of users, and that clearly links the investment in campus-wide information resources to the effectiveness of particular disciplinary programs."

University regents, administrators and users need to be educated to the changing (and limited) value of current ranking systems for comparisons between libraries. Libraries cannot afford to be constrained in moving ahead with major changes that may initially effect the libraries' rankings in negative ways.

\section{FIGURES:}

Table 1 Holdings for Research Libraries 1996 to 1997

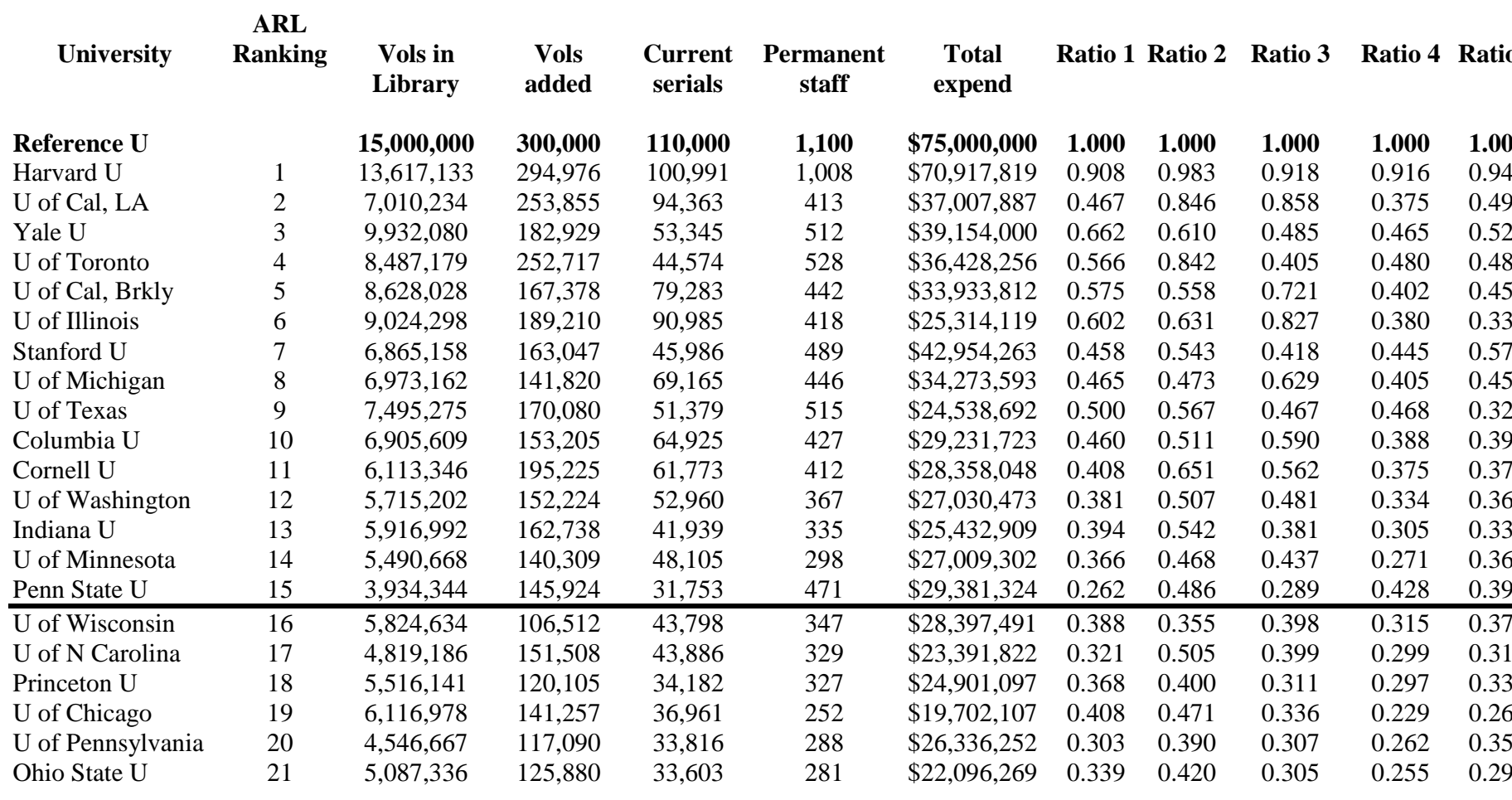




\begin{tabular}{lccccccccccc}
\multicolumn{1}{c}{ University } & $\begin{array}{c}\text { ARL } \\
\text { Ranking }\end{array}$ & $\begin{array}{c}\text { Vols in } \\
\text { Library }\end{array}$ & $\begin{array}{c}\text { Vols } \\
\text { added }\end{array}$ & $\begin{array}{c}\text { Current } \\
\text { serials }\end{array}$ & $\begin{array}{c}\text { Permanent } \\
\text { staff }\end{array}$ & $\begin{array}{c}\text { Total } \\
\text { expend }\end{array}$ & Ratio 1 Ratio 2 & Ratio 3 & Ratio 4 Ratio \\
New York U & 22 & $3,629,897$ & 131,255 & 29,247 & 339 & $\$ 24,242,867$ & 0.242 & 0.438 & 0.266 & 0.308 & 0.32 \\
U of Virginia & 23 & $4,433,628$ & 87,144 & 45,398 & 299 & $\$ 23,248,612$ & 0.296 & 0.290 & 0.413 & 0.272 & 0.31 \\
Duke U & 24 & $4,645,050$ & 115,788 & 32,003 & 288 & $\$ 21,574,509$ & 0.310 & 0.386 & 0.291 & 0.262 & 0.28 \\
Rutgers U & 25 & $3,633,792$ & 96,681 & 29,005 & 346 & $\$ 24,785,416$ & 0.242 & 0.322 & 0.264 & 0.315 & 0.33 \\
U of B Columbia & 26 & $3,853,442$ & 142,996 & 18,784 & 337 & $\$ 21,121,587$ & 0.257 & 0.477 & 0.171 & 0.306 & 0.28 \\
Arizona State U & 27 & $3,278,332$ & 106,174 & 36,401 & 306 & $\$ 19,618,004$ & 0.219 & 0.354 & 0.331 & 0.278 & 0.26 \\
U of Alberta & 28 & $5,189,177$ & 110,213 & 25,993 & 271 & $\$ 16,731,039$ & 0.346 & 0.367 & 0.236 & 0.246 & 0.22 \\
U of Arizona & 29 & $4,442,961$ & 112,241 & 25,171 & 266 & $\$ 19,712,136$ & 0.296 & 0.374 & 0.229 & 0.242 & 0.26 \\
U of Iowa & 30 & $3,822,656$ & 110,813 & 39,138 & 224 & $\$ 18,652,223$ & 0.255 & 0.369 & 0.356 & 0.204 & 0.24 \\
\hline
\end{tabular}




\begin{tabular}{|c|c|c|c|c|c|c|c|c|c|c|c|}
\hline University & $\begin{array}{c}\text { ARL } \\
\text { Ranking }\end{array}$ & $\begin{array}{l}\text { Vols in } \\
\text { Library }\end{array}$ & $\begin{array}{c}\text { Vols } \\
\text { added }\end{array}$ & $\begin{array}{c}\text { Current } \\
\text { serials }\end{array}$ & $\begin{array}{c}\text { Permanent } \\
\text { staff }\end{array}$ & $\begin{array}{c}\text { Total } \\
\text { expend }\end{array}$ & Ratio 1 & Ratio 2 & Ratio 3 & Ratio 4 & Ratio \\
\hline $\mathrm{U}$ of Georgia & 32 & $3,458,298$ & 74,334 & 45,258 & 287 & $\$ 17,333,876$ & 0.231 & 0.248 & 0.411 & 0.261 & \\
\hline U of Pittsburgh & 33 & $3,819,100$ & 95,132 & 24,996 & 281 & $\$ 19,274,840$ & 0.255 & 0.317 & 0.227 & 0.255 & \\
\hline $\mathrm{U}$ of Florida & 34 & $3,317,781$ & 81,863 & 24,788 & 316 & $\$ 18,475,394$ & 0.221 & 0.273 & 0.225 & 0.287 & \\
\hline $\mathrm{U}$ of S California & 35 & $3,417,928$ & 79,037 & 27,937 & 239 & $\$ 21,935,490$ & 0.228 & 0.263 & 0.254 & 0.217 & \\
\hline $\mathrm{U}$ of Cal, Davis & 36 & $2,949,213$ & 86,556 & 45,665 & 228 & $\$ 16,289,233$ & 0.197 & 0.289 & 0.415 & 0.207 & \\
\hline Mich State U & 37 & $4,118,032$ & 104,156 & 27,184 & 165 & $\$ 15,802,378$ & 0.275 & 0.347 & 0.247 & 0.150 & \\
\hline $\mathrm{U}$ of Kansas & 38 & $3,532,810$ & 84,168 & 33,264 & 198 & $\$ 14,974,010$ & 0.236 & 0.281 & 0.302 & 0.180 & \\
\hline Johns Hopkins U & 39 & $3,224,741$ & 62,675 & 21,215 & 271 & $\$ 20,531,044$ & 0.215 & 0.209 & 0.193 & 0.246 & \\
\hline Washington U & 40 & $3,234,005$ & 91,740 & 18,628 & 231 & $\$ 18,427,197$ & 0.216 & 0.306 & 0.169 & 0.210 & \\
\hline Texas A \&M & 41 & $2,447,598$ & 91,510 & 22,781 & 263 & $\$ 17,071,590$ & 0.163 & 0.305 & 0.207 & 0.239 & \\
\hline N Carolina St U & 42 & $2,618,615$ & 84,303 & 26,450 & 226 & $\$ 16,780,431$ & 0.175 & 0.281 & 0.240 & 0.205 & \\
\hline $\mathrm{U}$ of $\mathrm{Cal}, \mathrm{SD}$ & 43 & $2,531,418$ & 82,868 & 22,885 & 241 & $\$ 17,802,109$ & 0.169 & 0.276 & 0.208 & 0.219 & \\
\hline U of Maryland & 44 & $2,626,800$ & 92,203 & 27,136 & 214 & $\$ 15,603,070$ & 0.175 & 0.307 & 0.247 & 0.195 & \\
\hline Emory U & 45 & $2,369,065$ & 72,273 & 24,021 & 252 & $\$ 19,349,321$ & 0.158 & 0.241 & 0.218 & 0.229 & \\
\hline Georgetown U & 46 & $2,172,213$ & 85,635 & 27,503 & 207 & $\$ 17,420,794$ & 0.145 & 0.285 & 0.250 & 0.188 & \\
\hline Wayne State U & 47 & $3,002,261$ & 66,806 & 24,105 & 199 & $\$ 17,105,100$ & 0.200 & 0.223 & 0.219 & 0.181 & \\
\hline U of Utah & 48 & $2,608,118$ & 74,556 & 15,327 & 257 & $\$ 18,149,937$ & 0.174 & 0.249 & 0.139 & 0.234 & \\
\hline UNM & 49 & $2,175,706$ & $\mathbf{8 8 , 0 8 0}$ & 17,469 & 253 & $\$ 17,087,941$ & 0.145 & 0.294 & 0.159 & 0.230 & \\
\hline Brown U & 50 & $2,932,818$ & 121,509 & 13,278 & 181 & $\$ 14,778,852$ & 0.196 & 0.405 & 0.121 & 0.165 & \\
\hline St U of NY, Buff & 51 & $3,047,830$ & 75,994 & 21,129 & 184 & $\$ 13,974,189$ & 0.203 & 0.253 & 0.192 & 0.167 & \\
\hline U of Kentucky & 52 & $2,679,084$ & 49,533 & 26,142 & 214 & $\$ 15,493,171$ & 0.179 & 0.165 & 0.238 & 0.195 & \\
\hline U of Notre Dame & 53 & $2,583,669$ & 69,670 & 23,903 & 202 & $\$ 13,547,022$ & 0.172 & 0.232 & 0.217 & 0.184 & \\
\hline U of S Carolina & 54 & $2,998,228$ & 69,764 & 18,051 & 198 & $\$ 14,222,819$ & 0.200 & 0.233 & 0.164 & 0.180 & \\
\hline U of Connecticut & 55 & $2,828,359$ & 64,781 & 18,604 & 174 & $\$ 17,180,186$ & 0.189 & 0.216 & 0.169 & 0.158 & \\
\hline U of Colorado & 56 & $2,715,702$ & 50,533 & 28,473 & 176 & $\$ 15,648,969$ & 0.181 & 0.168 & 0.259 & 0.160 & \\
\hline Vanderbilt U & 57 & $2,442,771$ & 60,422 & 19,768 & 221 & $\$ 14,526,764$ & 0.163 & 0.201 & 0.180 & 0.201 & \\
\hline McGill U & 58 & $2,994,156$ & 60,006 & 16,424 & 226 & $\$ 12,971,447$ & 0.200 & 0.200 & 0.149 & 0.205 & \\
\hline Boston U & 59 & $2,086,258$ & 53,395 & 28,934 & 204 & $\$ 13,032,502$ & 0.139 & 0.178 & 0.263 & 0.185 & \\
\hline $\mathrm{UC}$ at San Barb & 60 & $2,396,611$ & 98,024 & 17,976 & 150 & $\$ 12,976,039$ & 0.160 & 0.327 & 0.163 & 0.136 & \\
\hline Average figures: & & $4,469,513$ & 115,116 & 36,472 & 305 & $\$ 22,363,507$ & 0.298 & 0.384 & 0.332 & 0.277 & \\
\hline
\end{tabular}

\section{NOTES:}

Dole, W.V. (1994). Myth and reality: Using the OCLC/AMIGOS Collection Analysis CD to measure collections against peer collections and against institutional priorities. Library

Acquisitions - Practice and theory Summer, 18: 179-192.

Keith,F. (1997). The self-sufficient library collection: A test of assumptions. Journal of the American Society for Information Science 48: 11-16.

Kyrillidou, M. (1995) Developing indicators for academic library performance: ratios from the ARL statisctics 1992-93 and 1993-94. Washington, DC: Association of Research Libraries.

Lindauer, B.G. (1998). Defining and measuring the library's impact on campuswide outcomes.

College \& Research Libraries 59: 546-570. 
Pritchard, S.M. (1996). Determining quality in academic libraries. Library Trends Winter, 44:

$577-594$.

\section{NOTES:}

ARL New Measures Initiative. Available at (ARL February 12, 2001)

http://www.arl.org/stats/newmeas/newmeas.html.

For specific articles on this initiative consult the ARL Bimonthly Report topics section available at http://www.arl.org/newsltr/meas.html

LibQUAL+ is a research and development project undertaken to define and measure library service quality across institutions and to create useful quality-assessment tools for local planning.

Available (ARL May 12, 2001) http://www.arl.org/libqual/

- van Reenen is the Head of Public Services and the Director of the Centennial Science \& Engineering Library at the University of New Mexico Libraries, Albuquerque, NM

- E-mail jreenen@unm.edu Homepage http://www.unm.edu/ jreenen 